\title{
Self-efficacy dan Kemampuan Mendengar Aktif Konselor Sebaya terhadap Kesehatan Mental
}

\author{
Qurrota A'yuni Fitriana', Hamim Rosyidi ${ }^{1}$ \\ 1Fakultas Psikologi dan Kesehatan UIN Sunan Ampel Surabaya
}

DOI: http://doi.org/10.29080/jpp.v12i2.631

\begin{abstract}
Peer counselors should have self-confidence and basic techniques in counseling like active listening skills. This research aims to study the role of self-efficacy and active listening skills among peer counselors to prevent mental health problems due to the Covid 19 pandemic. There were 27 students, graduated students majoring in psychology or counseling involved in this study. Having quantitative method, data was analyzed using multiple regression. The results showed that self-efficacy and active listening ability of peer counselors had no role in preventing mental health problems both partially and simultaneously. However, both self-efficacy and active listening ability affect $2.7 \%$ of peer counselors preventing mental health problems.
\end{abstract}

Kata kunci : self-efficacy, active listening skill, peer counselor, mental health

\begin{abstract}
Abstrak : Konselor sebaya diharapkan memiliki keyakinan diri serta mampu menguasai teknik dasar dalam konseling seperti kemampuan mendengar aktif. Penelitian ini bertujuan untuk mengetahui peran self-efficacy dan kemampuan mendengar aktif pada konselor sebaya dalam perannya mencegah masalah kesehatan mental akibat pandemi Covid 19. Subyek penelitan berjumlah 27 orang yang merupakan mahasiswa/lulusan jurusan psikologi/bimbingan konseling dan pernah mengikuti pelatihan konseling sebaya. Menggunakan metode penelitian kuantitatif, data dianalisis dengan regresi berganda. Hasil penelitian menunjukkan bahwa self-efficacy dan kemampuan mendengar aktif pada konselor sebaya tidak menunjukkan peran terhadap pencegahan masalah kesehatan mental baik secara parsial maupun simultan. Namun ditemukan $2,7 \%$ pengaruh self-efficacy dan kemampuan mendengar aktif pada konselor sebaya secara bersama-sama terhadap pencegahan masalah kesehatan mental dampak pandemi covid 19.
\end{abstract}

Kata kunci : self efficacy, kemampuan mendengar aktif, konselor sebaya, kesehatan metal

\section{Pendahuluan}

Corresponding Author: Qurrota A'yuni Fitriana (e-mail: qayunif@gmail.com) Program Studi Psikologi Fakultas Psikologi dan Kesehatan UIN Sunan Ampel Surabaya, Jl. A. Yani 117 Surabaya Jawa Timur, Indonesia 60237 
Pandemi Covid-19 menjadi ancaman bagi kesehatan fisik dan mental karena masyarakat lebih rentan terhadap stres (Bartoszek et al., 2020; Bijulakshmi et al., 2020; Ridlo, 2020; Wang et al., 2020). Melihat kondisi kesehatan mental pada remaja dan dibutuhkan penanganan awal untuk mencegah masalah kesehatan mental yang lebih mendalam. Konseling sebaya merupakan usaha dalam memberikan bantuan interpersonal yang dilakukan oleh nonprofesional, serta dilaksanakan di bawah pendampingan konselor yang berkualifikasi (Muslikah et al., 2016). Konseling teman sebaya memudahkan remaja untuk membuka diri karena memiliki pengalaman dan masalah yang sama sehingga mereka lebih mudah untuk mencari solusi (Salmiati et al., 2018).

Konselor sebaya diharapkan memiliki keyakinan diri dalam melakukan proses konseling. Self-efficacy dapat diartikan sebagai keyakinan yang dimiliki seseorang terhadap kemampuannya untuk mengelola perilakunya dalam melakukan suatu tugas, mengatasi rintangan, dan mencapai tujuan yang telah ditetapkan (Bandura, 1997). Dalam melakukan konseling, konselor sebaya seringkali tidak percaya diri karena keterbatasan pengetahuan (Ismiyati et al., 2019). Tantangan lain yang dihadapi oleh konselor sebaya ialah sikap konseli yang kurang terbuka, konselor kurang mampu mengenali dan menetapkan jenis masalah yang dihadapi konseli, dan lupa menanyakan perasaan konseli setelah melakukan konseling sebaya (Sari et al., 2020).

Konselor sebaya seharusnya memiliki keahlian yang cukup memadai dalam melakukan proses konseling sebaya. Arudo (2008) menggambarkan sejumlah kualifikasi sebagai konselor sebaya seperti mudah bergaul, disiplin, prestasi akademik minimal ratarata, pembicara yang baik, pendengar dan mampu menjaga rahasia. Konselor sebaya juga harus memiliki sikap keterbukaan, pengertian, komunikasi yang baik, kerendahan hati, empati, disiplin dan pandai mendengarkan (Lutomia \& Sikolia, 2002).

Salah satu kemampuan penting yang seringkali diabaikan dalam konseling adalah ialah kemampuan mendengar (L Arnold, 2014). Mendengar aktif bermula dari teori humanistik person centered dari Carl Rogers, yaitu merupakan sikap paling dasar dalam mendengarkan orang lain secara efektif dan tidak pasif (Rogers, 1979). Mendengar aktif meliputi kegiatan merumuskan pertanyaan yang sesuai, melakukan paraphrase dan meringkas, menyatakan komentar, mengungkapkan pemahaman yang lebih lengkap serta memverifikasi hal-hal yang sudah diungkapkan. Hal ini termasuk juga melakukan dan menjaga kontak mata, menggunakan gerakan non-verbal seperti mengangguk atau tersenyum, dan tidak menyela pembicara (Weger et al., 2010). Mendengarkan secara aktif dikembangkan sebagai salah satu teknik dasar konseling yang memiliki sifat terapeutik (Rogers, 1979). Sehingga penelitian ini bertujuan untuk mengetahui peran self efficacy dan kemampuan mendengar aktif pada konselor sebaya dalam perannya mencegah masalah kesehatan mental akibat pandemi Covid 19.

\section{Metode Penelitian}

Penelitian ini menggunakan dua variabel bebas yaitu self-efficacy (X1) dan kemampuan mendengar aktif (X2) serta variabel terikat yaitu masalah kesehatan mental (Y). Populasi penelitian ialah mahasiswa atau lulusan dari jurusan psikologi dan bimbingan konseling. Kriteria sampel berasal dari jurusan psikologi dan bimbingan konseling, pernah mendapatkan pelatihan mengenai konseling sebaya dalam 4 tahun terakhir, dan pernah menjadi seorang konselor sebaya. Sampel yang didapatkan sejumlah 27 orang yang berusia 19 hingga 25 tahun. Pengambilan data menggunakan skala secara online, sehingga peserta dari lokasi manapun dapat mengerjakannya. Teknik sampling yang digunakan ialah simple random sampling.

Variabel self-efficacy diukur menggunakan general self-efficacy scale untuk menilai keyakinan yang dimiliki oleh individu dalam mengatasi masalah yang ada di dalam 
kehidupan. Skala ini disusun oleh Matthias Jerusalem dan Ralf Schwarzer di tahun 1981. Skala ini berawal dari Bahasa Jerman dan telah diterjemahkan ke dalam 32 bahasa termasuk Bahasa Indonesia (Born, et.al, 1995).

Untuk menilai keterampilan mendengarkan aktif alat ukur yang digunakan adalah adaptasi Active Listening Attitude Scale (ALAS) dari Yunani. ALAS memiliki tiga sub-skala yaitu sikap mendengarkan, yang mengacu pada "pemahaman empatik" atau "penghargaan positif tanpa syarat", keterampilan mendengarkan, yang menjelaskan lebih banyak aspek teknis dari mendengarkan secara aktif dan conversation opportunity, yang mengukur kapan momen dalam mengambil kesempatan untuk berbicara dan mendengarkan secara aktif (Kourmousi et al., 2017). Skala ini memiliki koefisien reliabilitas 0,72 dan nilai interkorelasi dari tiga sub-skala seluruhnya positif dan signifikan $(p<0,001)$, mulai dari 0,20 hingga 0,42 .

Sedangkan untuk skala pencegahan masalah kesehatan mental, menggunakan kueisoner yang terdiri dari 32 aitem mengacu pada lima masalah psikososial yang ilaporkan paling banyak muncul selama pandemic. Hambatan belajar, stress, cemas, masalah mood dan masalah somatis adalah contoh gejala kesehatan mental yang terjadi. Skala ini memiliki koefisien reliabilitas antara 0,894 dan validitas 0,73. Analisis data menggunakan teknik analisis regresi linier berganda untuk mengetahui peran masingmasing variable $\mathrm{X}$ baik secara parsial maupun simultan terhadap variabel $\mathrm{Y}$.

\section{Hasil Penelitian}

Sebelum melakukan uji regesi ganda dilakukan terlebih dahulu uji asumsi klasik. Hasil uji normalitas dengan Kolmogorov Smirnov menunjukkan data memiliki distribusi normal dengan $\mathrm{p}=0,2>0,05$. Selanjutnya uji multikolinieritas menunjukkan hasil nilai tolerance $0,780>0,1$ dan nilai VIF $1,282<10,00$ yang artinya variable tidak mengalami multikolinieritas. Adapun uji autokolinieritas dengan Durbin Watson didapatkan nilai $\mathrm{p}=1,453$ menunjukkan hubungan antara variabel independen dan variabel dependen adalah linear dimana. Berikutnya uji heteroskedastisitas menunjukkan hasil bahwa tidak ada gejala heteroskedasitas sehingga dapat dilakukan uji regresi.

Tabel 1

\section{Hasil Uji Regresi Ganda}

\begin{tabular}{|c|c|c|c|c|c|c|}
\hline \multicolumn{7}{|c|}{ Coefficients $^{a}$} \\
\hline \multirow{2}{*}{\multicolumn{2}{|c|}{ Model }} & \multicolumn{2}{|c|}{$\begin{array}{l}\text { Unstandardized } \\
\text { Coefficients }\end{array}$} & \multirow{2}{*}{$\begin{array}{c}\text { Standardized } \\
\text { Coefficients }\end{array}$} & \multirow[t]{2}{*}{$\mathrm{t}$} & \multirow[t]{2}{*}{ Sig. } \\
\hline & & B & Std. Error & & & \\
\hline \multirow[t]{3}{*}{1} & (Constant) & 99.692 & 27.027 & & 3.689 & .001 \\
\hline & $\begin{array}{l}\text { Self } \\
\text { Efficacy }\end{array}$ & -.532 & .729 & -.166 & -.729 & .473 \\
\hline & $\begin{array}{l}\text { Skill } \\
\text { Listening }\end{array}$ & .006 & .320 & .004 & .019 & .985 \\
\hline
\end{tabular}

Berdasarkan perhitungan yang telah dilakukan, hasil penelitian yang menunjukkan bahwa secara parsial self efficacy dari konselor sebaya tidak memiliki peran terhadap pencegahan masalah kesehatan mental dengan nilai Sig 0,473 >0,05. Begitu juga dengan keterampilan mendengar aktif secara parsial tidak memiliki peran yang signifikan dalam pencegahan kesehatan mental dengan nilai Sig 0,985 >0,05. Sedangkan secara simultan, self efficacy dan kemampuan mendengar aktif pada konselor sebaya juga tidak menunjukkan peran yang signifikan dengan nilai Sig F 0,720>0,05.

\section{Tabel 2}

\section{Model Summary}




\begin{tabular}{ccrrrr}
\hline Model & R & R Square & $\begin{array}{c}\text { Adjusted R } \\
\text { Square }\end{array}$ & $\begin{array}{c}\text { Std. Error of } \\
\text { the Estimate }\end{array}$ & $\begin{array}{c}\text { Durbin- } \\
\text { Watson }\end{array}$ \\
\hline 1 & $.164^{\mathrm{a}}$ & .027 & -.054 & 12.122 & 1.453 \\
\hline
\end{tabular}

Meski demikian, ditemukan sumbangan efektif self efficacy dan kemampuan mendengar aktif pada konselor sebaya secara bersama-sama terhadap pencegahan masalah kesehatan mental dampak pandemi covid 19 sebesar 2,7\%.

\section{Pembahasan}

Hadirnya pandemi Covid-19 menjadi penyebab masalah psikologis bagi penduduk dunia. Mulai dari usia anak, remaja, dewasa hingga lanjut usia. Hal ini juga terjadi pada siswa sekolah yang mengharuskan mereka belajar secara online di rumah. Meskipun terbukti menjadi alternatif yang paling efektif untuk menggantikan pembelajaran secara tatap muka, namun belajar online menjadi satu sumber masalah kesehatan mental yang utama bagi siswa terutama di tingkat akhir (Akpınar, 2021; Zeng et al., 2021). Data dari beberapa negara juga menunjukkan bahwa masyarakat lebih rentan terhadap stres dan sering mengalami kecemasan akibat pandemi (Bartoszek et al., 2020; Bijulakshmi et al., 2020; Ridlo, 2020; Wang et al., 2020). Khususnya di Indonesia, masalah psikososial yang paling banyak dialami ialah hambatan dalam belajar, stress umum, masalah kecemasan, masalah mood dan masalah somatis (IPK, 2020).

Penanganan awal perlu dilakukan untuk mencegah masalah kesehatan mental lebih mendalam, salah satunya yaitu dengan melakukan konseling sebaya. Konseling sebaya memiliki peran yang signifikan terhadap kesehatan mental (Salsabila et al., 2020). Hal ini dikarenakan dalam proses konseling akan ada pertukaran informasi dari konselor dan konseli yang memiliki pengalaman serupa serta perbedaan usia yang tidak jauh sehingga menimbulkan proses pemahaman di dalamnya.

Konselor sebaya diharapkan memiliki self-efficacy dalam melakukan tugas yang dihadapinya. Dalam prosesnya, konselor sebaya menghadapi berbagai tantangan, seperti munculnya rasa tidak percaya diri yang bersumber dari keterbatasan pengetahuan yang cukup mengenai konseling sebaya (Ismiyati et al., 2019). Tantangan lain yang dihadapi oleh konselor sebaya ialah sikap konseli yang kurang terbuka, konselor kurang mampu mengenali dan menetapkan jenis masalah yang dihadapi konseli, dan lupa menanyakan perasaan konseli setelah melakukan konseling sebaya (Sari et al., 2020). Namun demikian, hasil penelitian ini menunjukkan self-efficacy pada konselor sebaya tidak memiliki peran yang signifikan dalam upaya pencegahan masalah kesehatan mental akibat pandemi covid 19.

Terdapat studi yang menyebutkan bahwa self-efficacy memiliki interaksi dengan stress yang menantang yang dirasakan dapat memengaruhi kesehatan mental pada siswa (Zeng et al., 2021). Artinya, self-efficacy merupakan sebuah hal yang dibutuhkan oleh setiap orang untuk menyelesaikan suatu tantangan dengan sebaik-baiknya. Tantangan tersebut dapat merupakan stress saat belajar yang dialami oleh setiap siswa maupun tantangan yang dihadapi oleh konselor sebaya dalam menjalani proses konseling sebaya. Secara khusus, terdapat studi yang menunjukkan bahwa ketika menghadapi tingkat stres yang tinggi, individu dengan efikasi diri yang lebih tinggi cenderung lebih berhasil mengelola stres yang datang (Zhao, et. al, 2015). Namun terdapat hasil studi yang berbeda dimana self-efficacy tidak berdampak pada stres dan kesehatan mental di antara guru sekolah Cina (Chan, 2002). Dalam hal ini, konselor sebaya pun perlu untuk memiliki selfefficacy yang tinggi terlebih dahulu untuk menyelesaikan tantangan yang dihadapi secara pribadi. Namun hal ini tidak selalu membuatnya memiliki self-efficacy yang tinggi dalam menjalani peran sebagai konselor sebaya. 
Konselor sebaya diharapkan memiliki keahlian dalam melakukan proses konseling sebaya. Partisipan dalam penelitian memiliki latar belakang pendidikan dari jurusan psikologi dan bimbingan konseling dimana mereka memiliki dasar dalam melakukan konseling. Dari beberapa keterampilan yang dibutuhkan, salah satu keterampilan yang sering terlupakan adalah keterampilan mendengar secara aktif (L Arnold, 2014). Mendengar aktif meliputi kegiatan merumuskan pertanyaan yang sesuai, melakukan paraphrase dan meringkas hingga menggunakan gerakan non-verbal seperti mengangguk atau tersenyum (Weger et al., 2010). Mendengarkan secara aktif dikembangkan sebagai salah satu teknik dasar konseling yang memiliki sifat terapeutik (Rogers, 1979). Mendengar aktif merupakan keterampilan mikro yang perlu ditekankan pada konselor pemula agar ia dapat bekerja lebih efisien dan lebih mampu mendengar konseli. Studi menunjukkan penekanan pada keterampilan mendengar aktif dalam proses supervisi konselor sebaya, dapat meningkatkan kemampuan mendengar secara aktif serta tingkat self-efficacy yang dimiliki serta keterampilan lain seperti refleksi perasaan, ragam tantangan, dan sikap kehadiran. Hal ini menunjukkan bahwa kedua hal yaitu kemampuan mendengar aktif serta self-efficacy pada diri konselor penting dalam mengurangi kecemasan dalam pengalaman konseling pertama (Levitt, 2002).

Meski demikian, keterampilan mendengar aktif pada konselor sebaya tidak memiliki peran yang signifikan dalam pencegahan masalah kesehatan mental akibat pandemi covid 19. Hal ini dapat diartikan bahwa ketrampilan mendengar aktif pada konselor sebaya tidak memberikan peran meskipun mendengar aktif memberikan efek terapeutik dalam proses konseling. Terdapat keterampilan dasar lain yang juga perlu dikuasai yaitu adanya empati, kemampuan untuk hadir, bertanya, dan memperhatikan gesture non verbal yang dimunculkan oleh konseli selama proses konseling. Terdapat hasil penelitian yang menunjukkan bahwa keberhasilan dalam konseling lebih tergantung pada kualitas pribadi konselor daripada penggunaan yang benar dari teknik tertentu (Tyler, 1961).

Meski demikian, secara bersamaan self efficacy dan kemampuan mendengar aktif pada konselor sebaya memiliki sumbangan efektif sebesar 2,7\% dalam mencegah masalah kesehatan mental akibat pandemi Covid 19. Dengan kata lain 97,3\% lainnya terdapat faktor-faktor yang perlu dieksplorasi lebih dalam mengenai peran konselor sebaya dalam mencegah masalah kesehatan mental.

\section{Simpulan dan Saran}

Adanya konseling sebaya yang dilakukan konselor sebaya merupakan suatu langkah yang bisa dilakukan dalam melakukan intervensi awal dalam masalah kesehatan mental akibat pandemi covid 19. Dalam penelitian ini self-efficacy dan keterampilan mendengar aktif tidak memiliki peran yang signifikan dalam mencegah masalah kesehatan mental pada individu. Namun perlu adanya penelitian lanjutan berkaitan dengan pemberian keterampilan yang lebih terstruktur dan sistematis pada konselor sebaya serta melakukan program yang diawali oleh screening mengenai karakteristik individu yang memiliki keahlian sebagai konselor sebaya untuk dilibatkan dalam proses pencegahan masalah kesehatan mental.

\section{Daftar Pustaka}

Akpınar, E. (2021). The Effect of Online Learning on Tertiary Level Students' Mental Health during the Covid19 Lockdown. The European Journal of Social \& Behavioural Sciences, 30(1). https://doi.org/10.15405/ejsbs.288

Arudo, T. O. 0. (2008). Peer Counseling Experience Among Selected Kenyan Secondary Schools. ProQuest Dissertations and Theses, 1-23. 
Bandura, A. (1997). Self Efficacy The Exercise of Control. New York: W. H. Freeman and Company.

Bartoszek, A., Walkowiak, D., Bartoszek, A., \& Kardas, G. (2020). Mental well-being (Depression, loneliness, insomnia, daily life fatigue) during COVID-19 related homeconfinement-A study from Poland. International Journal of Environmental Research and Public Health, 17(20), 1-12. https://doi.org/10.3390/ijerph17207417

Bijulakshmi, P., Ramasubramanian, V., Mathumathi, M., Rajendhiran, G., \& C, R. (2020). Psychological Impact of COVID 19 on the Amount of Perceived Stress among College Students Studying across Various Streams in India during the Period of Lockdown. Journal of Evolution of Medical and Dental Sciences, 9(39). https://doi.org/10.14260/jemds/2020/632

Born, A., Schwarzer, S., Jerusalem, M. (1995). General Self-Efficacy Scale retrieved from http://userpage.fu-berlin.de/ health/indonese.htm. Accessed August 18, 2021.

Chan, D. W. (2002). Stress, self-efficacy, social support, and psychological distress among prospective Chinese teachers in Hong Kong. Educational Psychology, 22(5), 557-569. DOI 10.1080/0144341022000023635.

IPK, S. untuk P. C. 19 I. P. K. (2020). Media Kit Kiprah Psikolog Klinis untuk Indonesia di Masa Pandemi (Vol. 1).

Ismiyati, Walessa, R., Sunjaya, D. K., \& Susanah, S. (2019). Model Modul Konseling Sebaya Tentang Models of Peer Counselling Modules About Adolescents Reproductive Health. Medikes (Media Informasi Kesehatan), 6(November), 273-286.

Kourmousi, N., Amanaki, E., Tzavara, C., \& Koutras, V. (2017). Active listening attitude scale (ALAS): Reliability and validity in a nationwide sample of greek educators. Social Sciences, 6(1). https://doi.org/10.3390/socsci6010028

L Arnold, C. (2014). Listening: The Forgotten Communication Skill. Journal of Mass Communication \& Journalism, 04(10), 7912. https://doi.org/10.4172/2165$7912.1000 \mathrm{e} 155$

Levitt, D. H. (2020). Active listening and counselor self-efficacy: Emphasis on one microskill in beginning counselor training." The Clinical Supervisor. 20:2, 101-115. DOI: $10.1300 / J 001 v 20$ n02 09.

Lutomia, G., \& Sikolia, L. W. (2002). Guidance and Counselling in Schools and Colleges. Nairobi: Uzima Press

Muslikah, Hariyadi, S., \& Amin, Z. N. (2016). Pengembangan Model Peer Counseling Sebagai Media Pengalaman Praktik Konseling. Indonesian Journal of Guidance and Counseling, 5(3), 48-52. https://doi.org/10.15294/ijgc.v5i3.13509

Ridlo, I. A. (2020). Pandemi COVID-19 dan Tantangan Kebijakan Kesehatan Mental di Indonesia. INSAN Jurnal Psikologi Dan Kesehatan Mental, 5(2), 162. https://doi.org/10.20473/jpkm.v5i22020.162-171

Rogers, Carl R., and Richard E. Farson. "Active listening." Organizational Psychology (1979): 168-80.

Salmiati, S., Rosmawati, R., \& Lestari, M. (2018). Peer Counselor Training Untuk Mencengah Perilaku Bullying. Indonesian Journal of Learning Education and Counseling, 1(1), 62-69. https://doi.org/10.31960/ijolec.v1i1.37

Salsabila, Wiryantara, J., Salsabila, N., \& Alhad, M. A. (2020). The Role of Peer Counseling on Mental Health. Bisma The Journal of Counseling, 4(3), 242-253. https://ejournal.undiksha.ac.id/index.php/bisma

Sari, R., Saleh, M. N. I., Rahman, D. N., \& Aisah, A. (2020). Pemberdayaan Remaja Masjid di masa pandemi Covid-19 melalui workshop dan simulasi Konseling Sebaya. Counsellia: Jurnal Bimbingan Dan Konseling, 10(2). https://doi.org/10.25273/counsellia.v10i2.7789 
Schwarzer, R., \& Jerusalem, M. (1995). Generalized Self-Efficacy scale. In J. Weinman, S. Wright, \& M. Johnston, Measures in health psychology: A user's portfolio. Causal and control beliefs (pp. 3537). Windsor, England: NFER-NELSON.

Tindall, J. A., \& Gray, H. D. (1985). Peer Counseling: An in depth Look at Training Peer Helper (2nd edition). Muncie: Accelerated Development.

Tyler, L. E. (1961). The Work of the Counsellor. Appleton - Century Craff Inc, New York

Wang, S., Wen, X., Dong, Y., Liu, B., \& Cui, M. (2020). Psychological Influence of Coronovirus Disease 2019 (COVID-19) Pandemic on the General Public, Medical Workers, and Patients With Mental Disorders and its Countermeasures. Psychosomatics, 61(6), 616-624. https://doi.org/10.1016/j.psym.2020.05.005

Weger, H., Castle, G. R., \& Emmett, M. C. (2010). Active listening in peer interviews: The influence of message paraphrasing on perceptions of listening skill. International Journal of Listening, 24(1), 34-49. https://doi.org/10.1080/10904010903466311

Zeng, Y., Qiu, S., Alizadeh, A., \& Liu, T. (2021). How challenge stress affects mental health among college students during the COVID-19 pandemic: The moderating role of selfefficacy. International Journal of Mental Health Promotion, 23(2), 167-175. https://doi.org/10.32604/IJMHP.2021.015937

Zhao, F. F., Lei, X. L., He, W. (2015). The study of perceived stress, coping strategy and selfefficacy of Chinese undergraduate nursing students in clinical practice. International Journal of Nursing Practice, 21(4), 401-409. DOI 10.1111/ijn.12273. 